\title{
PELAKSANAAN PROSES DIAGNOSA KEPERAWATAN DALAM ASUHAN KEPERWATAN
}

\author{
Elisa Widyawati \\ elisawidyawati10@gmail.com
}

\section{LATAR BELAKANG}

Diagnosa keperawatan sebagai langkah kedua dari proses keperawatan. Diagnosa keperawatan merupakan keputusan klinik tentang respon individu, keluarga dan masyarakat tentang masalah kesehatan aktual atau potensial, dimana berdasarkan pendidikan dan pengalamannya, perawat secara akuntabilitas dapat mengidentifikasi dan memberikan intervensi secara pasti untuk menjaga, menurunkan, membatasi, mencegah dan merubah status kesehatan klien.

Asuhan keperawatan adalah kerangka kerja dan struktur organisasi yang kreatif untuk memberikan pelayanan keperawatan, namun asuhan keperawatan juga cukup fleksibel untuk digunakan disemua lingkup keperawatan (Potter \& Perry, 2005). Asuhan keperawatan yang bermutu akan dapat dicapai dengan pelaksanaan proses keperawatan yaitu metode pengorganisasian yang sistematis dalam melakukan asuhan keperawatan pada individu, kelompok, dan masyarakat yang berfokus pada identifikasi pemecahan masalah dari respon pasien terhadap penyakitnya. Proses keperawatan digunakan untuk membantu perawat melakukan praktik keperawatan yang terdiri dari lima tahap atau lima langkah, kelima langkah ini dilakukan berkesinambungan dengan melibatkan klien dan tenaga kesehatan lainnya. Setelah menyelesaikan pengkajian kritis dalam proses penegakan diagnosis, pilih diagnosis yang dapat dipakai untuk kebutuhan klien. diagnosa keperawatan sebagai langkah kedua dari proses keperawatan. Diagnosa keperawatan merupakan keputusan klinik tentang respon individu, keluarga dan masyarakat tentang masalah kesehatan aktual atau potensial, dimana berdasarkan pendidikan dan pengalamannya, perawat secara akuntabilitas dapat mengidentifikasi dan memberikan intervensi secara pasti untuk menjaga, menurunkan, membatasi, mencegah dan merubah status kesehatan klien (Herdman, 2012). 
Diagnosis keperawatan adalah suatu pernyataan yang menjelaskan respons manusia (status kesehatan atau risiko perubahan pola) dari individu atau kelompok dimana perawat secara akuntabilitas dapat mengidentifikasi dan memberikan intervensi secara pasti untuk menjaga kesehatan, menurunkan, membatasi, mencegah, dan mengubah (Carpeniro, 2000). Gordon (1976) mendefinisikan bahwa diagnosis keperawatan adalah masalah kesehatan aktual dan potensial dimana berdasarkan pendidikan dan pengalamannya, perawat mampu dan mempunyai kewenangan untuk memberikan asuhan keperawatan.

\section{METODE}

Pelaksanaan proses diagnosis keperawatan dalam memberikaan asuhan keperawatan menggunakan metode yakni teknik pengumpulan data dari berbagai sumber seperti textbook dan jurnal untuk mendapatkan data dan informasi yang lengkap dengan cara menyimpulkan dari 10jurnal dengan tahun paling tua 2012. Dengan mencari dari berbagai jurnal maupun textbook dapat mudah dipahami dan dimengerti serta menyimpulkan nya dengan bahasa sendiri.

\section{HASIL}

Diagnosis Association (NANDA) menyatakan bahwa diagnosis keperawatan adalah keputusan klinik mengenai respons individu (klien dan masyarakat) tentang masalah kesehatan aktual atau potensial sebagai dasar seleksi intervensi keperawatan untuk mencapai tujuan asuhan keperawatan sesuai dengan kewenangan perawat.

Penegakan diagnosis merupakan aspek penting dalam praktik keperawatan. Sepanjang waktu, format dan kualitas penegakan diagnosis telah berkembang, tetapi fokusnya terus berdampak terhadap perawatan klien (Potter \& Perry; 2009). Sistem penegakan diagnosis yang ideal harus memberikan informasi klien yang komprehensif, menunjukkan hasil dan standar klien, memfasilitasi reimbursement dari pemerintah dan dari perusahaan asuransi pembayar, serta berfungsi sebagai dokumen legal (Twardon dan Gartner, 1993: Potter \& Perry; 2009). Mutu asuhan keperawatan dapat tergambar dari penegakan diagnosis proses keperawatan (Gillies, 1994). Penegakan diagnosis dalam keperawatan memegang peranan penting terhadap segala 
macam tuntutan masyarakat yang semakin kritis dan mempengaruhi kesadaran masyarakat akan hak-haknya dari suatu unit kesehatan. Akuntabilitas perawat sebagai profesi diantaranya adalah kompetensinya dalam mendokumentasikan diagnosa keperawatan sesuai standar diagnosa keperawatan Indonesia (SDKI). Kompetensi ini dibutuhkan dalam rangka menjamin kualitas asuhan keperawatan kepada masyarakat.

Perawat harus sebagai 'Penegak Diagnosis' keperawatan yang sudah terstandar dan ditetapkan oleh organisasi profesi PPNI dan disahkan oleh menteri, yaitu Standar Diagnosis Keperawatan Indonesia (SDKI). Hal yang dimaksud dengan standar profesi adalah batasan kemampuan (capacity) meliputi pengetahuan (knowledge), keterampilan (skill), dan sikap professional (professional attitude) yang minimal harus dikuasai oleh seorang individu untuk dapat melakukan kegiatan profesionalnya pada masyarakat secara mandiri yang dibuat oleh organisasi profesi. Proses keperawatan telah diidentikan sebagai metoda ilmiah keperawatan untuk para penerima tindakan keperawatan. Kebanyakan sekolah-sekolah keperawatan sekarang memasukkan proses keperawatan sebagai sautu komponen dari konsep kerja konsepatual mereka.

\section{PEMBAHASAN}

Keperawatan merupakan suatu bentuk pelayanan profesional bersifat humanistik, menggunakan pendekatan holistik, dilakukan berdasarkan ilmu dan kiat keperawatan, berorientasi kepada kebutuhan objektif klien. Praktek keperawatan mengacu pada standar professional keperawatan dan menggunakan etika keperawatan sebagai tuntutan utama. Peningkatan mutu keperawatan dapat diperoleh jika perawat mampu melaksanakan asuhan keperawatan sesuai standar, yaitu mulai dari pengkajian sampai dengan evaluasi lengkap dengan dokumentasi. Perawat dituntut untuk selalu melaksanakan asuhan keperawatan yang benar atau rasional. Hal ini menegaskan wewenang perawat sebagai penegak diagnosis yang harus memiliki kemampuan diagnosis yang baik sebagai dasar mengembangkan rencana intervensi keperawatan dalam rangka mencapai peningkatan, pencegahan dan penyembuhan serta pemulihan kesehatan klien. Tahap diagnosa keperawatan memungkinkan perawat untuk 
menganalisis dan mensintesis data yang telah dikelompokkan yang dicantumkan dibawah pola kesehatan dan divisi diagnosa fungsional.

Asuhan keperawatan adalah kerangka kerja dan struktur organisasi yang kreatif untuk memberikan pelayanan keperawatan, namun asuhan keperawatan juga cukup fleksibel untuk digunakan disemua lingkup keperawatan (Potter \& Perry, 2005). Asuhan keperawatan yang bermutu akan dapat dicapai dengan pelaksanaan proses keperawatan yaitu metode pengorganisasian yang sistematis dalam melakukan asuhan keperawatan pada individu, kelompok, dan masyarakat yang berfokus pada identifikasi pemecahan masalah dari respon pasien terhadap penyakitnya Proses keperawatan digunakan untuk membantu perawat melakukan praktik keperawatan yang terdiri dari lima tahap atau lima langkah, kelima langkah ini dilakukan berkesinambungan dengan melibatkan klien dan tenaga kesehatan lainnya. Setelah menyelesaikan pengkajian kritis dalam proses penegakan diagnosis, pilih diagnosis yang dapat dipakai untuk kebutuhan klien. diagnosa keperawatan sebagai langkah kedua dari proses keperawatan.

Diagnosa keperawatan merupakan keputusan klinik tentang respon individu, keluarga dan masyarakat tentang masalah kesehatan aktual atau potensial, dimana berdasarkan pendidikan dan pengalamannya, perawat secara akuntabilitas dapat mengidentifikasi dan memberikan intervensi secara pasti untuk menjaga, menurunkan, membatasi, mencegah dan merubah status kesehatan klien (Herdman, 2012).

Diagnosis keperawatan adalah suatu pernyataan yang menjelaskan respons manusia (status kesehatan atau risiko perubahan pola) dari individu atau kelompok dimana perawat secara akuntabilitas dapat mengidentifikasi dan memberikan intervensi secara pasti untuk menjaga kesehatan, menurunkan, membatasi, mencegah, dan mengubah (Carpeniro, 2000). Gordon (1976) mendefinisikan bahwa diagnosis keperawatan adalah masalah kesehatan aktual dan potensial dimana berdasarkan pendidikan dan pengalamannya, perawat mampu dan mempunyai kewenangan untuk memberikan asuhan keperawatan. Kewenangan tersebut dapat diterapkan berdasarkan standar praktik keperawatan dan kode etik keperawatan yang berlaku di Indonesia. North American Nursing Diagnosis Association (NANDA) menyatakan bahwa diagnosis keperawatan adalah keputusan klinik mengenai respons individu (klien dan masyarakat) tentang masalah kesehatan aktual atau potensial sebagai dasar seleksi intervensi keperawatan untuk 
mencapai tujuan asuhan keperawatan sesuai dengan kewenangan perawat. Semua diagnosis keperawatan harus didukung oleh data, dimana menurut NANDA diartikan sebagai definisi karakteristik. Diagnosa keperawatan, sebagai suatu bagian dari proses keperawatan juga direfleksikan dalam standar praktik ANA. Standar-standar ini memberikan satu dasar luas mengevaluasi praktik dan merefleksikan pengakuan hak-hak manusia yang menerima asuhan keperawatan .

\section{PROSES PENYUSUNAN DIAGNOSA KEPERAWATAN}

1. Klasifikasi \& Analisis Data Pengelompokkan Data

Adalah mengelompokkan data-data klien atau keadaan tertentu dimana klien mengalami permasalahan kesehatan atau keperawatan berdasarkan kriteria permasalahannya. Pengelmpkkan data dapat disusun berdasarkan pola respon manusia (taksonomi NANDA) dan/atau pola fungsi kesehatan .

2. Interpretasi /Identifiikasi Kelebihan dan Masalah Klien Masalah Klien Merupakan keadaan atau situasi dimana klien perlu bantuan untuk mempertahankan atau meningkatkan status kesehatannya, atau meninggal dengan damai, yang dapat dilakukan oleh perawat sesuai dengan kemampuan dan wewenang yang dimilikinya. Identifikasi masalah klien dibagi menjadi : pasien tidak bermasalah, pasien yang kemungkinan mempunyai masalah, pasien yang mempunyai masalah potensial sehingga kemungkinan besar mempunyai masalah dan pasien yang mempunyai masalah aktual.

3. Memvalidasi Diagnosa Keperawatan Adalah menghubungkan dengan klasifikasi gejala dan tanda-tanda yang kemudian merujuk kepada kelengkapan dan ketepatan data. Untuk kelengkapan dan ketepatan data, kerja sama dengan klien sangat penting untuk saling percaya, sehingga mendapatkan data yang tepat. Pada tahap ini, perawat memvalidasi data yang ada secara akurat, yang dilakukan bersama klien/keluarga dan/atau masyarakat. Validasi tersebut dilaksanakan dengan mengajukan pertanyaan atau pernyataan yang reflektif kepada klien/keluarga tentang kejelasan interpretasi data. Begitu diagnosis keperawatan disusun, maka harus dilakukan validasi.

4. Menyusun Diagnosa Keperawatan Sesuai Dengan Prioritasnya 
Setelah perawat mengelompokkan, mengidentifikasi, dan memvalidasi data-data yang signifikan, maka tugas perawat pada tahap ini adalah merumuskan suatu diagnosis keperawatan. Diagnosa keperawatan dapat bersifat aktual, resiko, sindrom, kemungkinan dan wellness. Menyusun diagnosa keperawatan hendaknya diurutkan menurut kebutuhan yang berlandaskabn hirarki Maslow (kecuali untuk kasus kegawat daruratan menggunakan prioritas berdasarkan "yang mengancam jiwa”).

Persyaratan Penyusunan Diagnosis Keperawatan Perumusan harus jelas dan singkat dari respon klien terhadap situasi atau keadaan yang dihadapi

- Spesifi dan akurat (pasti)

- Dapat merupakan pernyataan dari penyebab

- Memberikan arahan pada asuhan keperawatan

- Dapat dilaksanakan oleh perawat pencerminan keadaan kesehatan klien

Komponen Diagnosis Keperawatan

Ada tiga komponen yang esensial dalam suatu diagnosa keperawatan yang telah dirujuk sebagai bentuk PES ( Gordon, 1987 ). “ $\mathrm{P}$ “ diidendtifikasi sebagai masalah/ problem kesehatan, "E” menunjukan etiologi/ penyebab dari problem, dan "S" menggambarkan sekelompok tanda dan gejala, atau apa yang dikenal sebagai " batasan karakteristik" ketiga bagian ini dipadukan dalam suatu pernyataan dengan menggunakan “ yang berhubungan dengan.” Kemudian diagnosadiagnosa tersebut dituliskan dengan cara berikut : Problem " yang berhubungan dengan “ etiologi” dibuktikanoleh“tanda-tanda dan gejalagejala(batasankarakteristik).

\section{HAL-HAL YANG PERLU DIPERHATIKAN DALAM MENENTUKAN DIAGNOSA KEPERAWATAN}

Berorientasi kepada klien, keluarga dan masyarakat

$>$ Bersifat aktual atau potensial

Dapat diatasi dengan intervensi keperawatan

Menyatakan masalah kesehatan individu, keluarga dan masyarakat, serta faktor-faktor penyebab timbulnya masalah tersebut. 


\section{ALASAN PENULISAN DIAGNOSA KEPERAWATAN}

- Memberikan asuhan keperawatan secara komprehensif

- Memberikan kesatuan bahasa dalam profesi keperawatan

- Meningkatkan komunikasi antar sejawat dan profesi kesehatan lainnya

- Membantu merumuskan hasil yang diharapkan / tujuan yang tepat dalam menjamin mutu asuhan keperawatan, sehingga pemilihan intervensi lebih akurat dan menjadi pedoman dalam melakukan evaluasi

- Menciptakan standar praktik keperawatan

- Memberikan dasar peningkatan kualitas pelayanan keperawatan.

\section{PENUTUP}

Diagnosa keperawatan adalah penilaian klinik tentang respon individu, keluarga, atau komunitas terhadap masalah kesehatan/proses kehidupan yang aktual atau potensial. Diagnosa keperawatan memberikan dasar untuk pemilihan intervensi keperawatan untuk mencapai hasil yang merupakan tanggung jawab perawat. Diagnosa keperawatan memberikan dasar untuk membuat kriteria hasil asuhan keperawatan dan menentukan intervensi-intervensi yang diperlukan untuk mencapai kriteria hasil. Perawat dituntut untuk selalu melaksanakan asuhan keperawatan yang benar atau rasional. Hal ini menegaskan wewenang perawat sebagai penegak diagnosis yang harus memiliki kemampuan diagnosis yang baik sebagai dasar mengembangkan rencana intervensi keperawatan dalam rangka mencapai peningkatan, pencegahan dan penyembuhan serta pemulihan kesehatan klien.

\section{DAFTAR PUSTAKA}

Apriyani, H. (2015). Identifikasi Diagnosis Keperawatan Pada Pasien Di Ruang Paru Di Sebuah Rumah Sakit. Jurnal Keperawatan, 11(1), 101-111.

Dermawan, D. (2012). Proses Keperawatan Penerapan Konsep dan Kerangka Kerja. Yogyakarta: Gosyen Publishing. 
Hidayati, R. (2020). Kompetensi perawat mendokumentasikan diagnosis keperawatan berdasarkan standar keperawatan diagnosis indonesia(SDKI). Jurnal ilmu kesehatan, 11(1), 234239.

Kasim, M., Abdurraouf, M. (2016). Peningkatan Kualitas Pelayanan dan pen dokumentasikan Asuhan Keperawatan Dengan Metode TIM. Nurseline Journal, 1,(1):63-64.

Kodim, Yulianingsih. (2015). Konsep Dasar Keperawatan. Jakarta: TIM.

Rachmania, D. (2016). Pengembangan Instrument Diagnosis \& Intervensi Keperawatan Berbasis Standardized Nursing Language (NANDA-I, NOC, NIC). Jurnal Ners. 11(2)

Rachmania, D., Nursalam., Yunitasari, E. (2016). Pengembangan instrumen diagnosis \& intervensi keperawatan berbasis standardized nursing language (NANDA, NOC, NIC). Jurnal Ners Vol 11 (2), 157-163.

Rosdahl, B.C \& Kowalski, T.M. (2014). Buku Ajar Keperawatan Dasar. Ed.10.Vol 1. Jakarta: EGC.

Rosdahl, Caroline Bunker. (2014). Buku Ajar Keperawatan Dasar.edisi 10. Jakarta: EGC.

Salmawati. (2013). Faktor yang Berhubungan dengan Pelaksanaan Dokumentasi Asuhan Keperawatan di Ruang Perawatan RSUD Labuang Baji Makassar. SKRIPSI-UIN Alauddin Makassar. Makassar: Tidak Dipublikasikan

Simamora, R. H., Bukit, E., Purba, J. M., \& Siahaan, J. (2017). Penguatan kinerja perawat dalam pemberian asuhan keperawatan melalui pelatihan ronde keperawatan di rumah sakit royal prima medan. Jurnal pengabdian kepada masyarakat, 23(2), 300-304.

Simamora, R. H. (2019). Socialization of Information Technology Utilization and Knowledge of Information System Effectiveness at Hospital Nurses in Medan, North Sumatra. Editorial Preface From the Desk of Managing Editor..., 10(9). 